UNITED STATES DEPARTMENT OF THE INTERIOR Harold L. Ickes, Secretary

GEOLOGICAL SURVEY

W. C. Mendenhall, Director

\title{
Bulletin 900-I
}

SUBSURFAGE GEOLOGY

AND OIL AND GAS RESOURCES OF OSAGE COUNTY, OKLAHOMA

Part 9. Townships 23 and 24 North

Range 7 East

BY

N. W. BASS, W. R. DILLARD, L. E. KENNEDY

AND H. B. GOODRICH

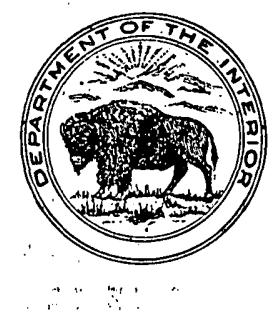

UNITED STATES

GOVERNMENT PRINTING OFFICE

WASHINGTON : 1941

For sale by the Superintendent of Documents, Washington, D. C. . - . - . - Price 25 cents 


\section{FOREWORD}

This report on the subsurface geology of Osage County, Okla., describes the structural features, the character of the oil- and gas-producing beds, and the lecalities where additional oil and gas may be found. It embodies a part of the $r \in$ Sults of a subsurface geologic investigation of the Osage Indian Reservation, which coincides in area with Osage County. The investigation was conducted by a field party of the Geological Survey of the United States Department of the Interior in 1934 to 1937 and involved the study of the records of about 17,000 wells that have been drilled in Osage County. Funds for the investigation were allotted to the Geological Survey by the Public Works Administration. The primary purpose of the examination was to obtain geologic data for use in the administration of the Indian lands. The results of the inquiry have shown that many localities in Osage County outside the present producing oil fields are worthy of prospecting for oil and gas and that additional oil and gas can be found also by exploring deeply buried beds in old producing fields.

All townships in Osage County that contain many wells are described; the iuformation furnished by such townships is ample for drawing detailed subsurface structure-contour maps. The descriptions of several contiguous townships are combined in separate reports, which are issued as parts of a single bulletin. No edition of the consolidated volume will be published, but the several parts can be bound together if desired.

The subsurface investigation of Osage County was carried on mainly by L. E. Kennedy, W. R. Dillard, H. B. Goodrich, Charles T. Kirk, J. D. McClure, Otto Leatherock, Constance Leatherock, W. E. Shamblin, J. N. Conley, H. D. Jenkins, J. H. Hengst, G. D. Gibson, and N. W. Bass, geologists. The work of each geologist contributed more or less to the results of the investigation in each township. However, the investigations of the individual townships in Osage County were made mainly by various individuals of the group, and their names appear in the township descriptions. In addition to those whose names appear above, valuable assistance in the compilation of information was given by Lucile Linton, S. B. Thomas, R. C. Beckstrom, B. A. Lilienborg, J. G. Dwen, K. H. Johnson, J. G. Beaulieu, C. R. Viers, E. L. Hitt, Grace Clark, R. A. Payne, and J. C. Rollins.

Oil companies and individuals who contributed information are too numerous to acknowledge all by name. Special mention is made, however, of LaughlinSimmons \& Co. and the Indian Territory Illuminating Oil Co. for supplying most of the well elevations used in Osage County; of the Continental Oil Co., Tidal Oil Co., Sinclair Prairie Oil Co., Indian Territory Illuminating Oil Co., Phillips Petroleum Co., W. C. McBride, Inc., The Carter Oil Co., and others for supplying well logs, maps, cuttings, and cores of the producing sands in Osage County.

H. D. Miser, geologist in charge of the section of geology of fuels, supervised the work upon which this report is based. Appreciative acknowledgment is here made of many suggestions made by him during the progress of the investigation and during the preparation of the manuscript. Grateful acknowledgment is due the officers of the Osage Indian Agency at Pawhuska and the late John M. Alden and others in the Tulsa office of the Geological Survey for cooperation and assistance; also Hale B. Soyster and H. I. Smith, of the Geological Survey, for sponsorship and interest in the investigation. :.

N. W. Bass. 


\section{CONTENTS}

Abstract. .

Introduction ...

Oil- and gas-producing beds_.

Siliceous lime and Simpson formation

Mississippi lime..... 305

Burbank sand .

Skinner sand...

Layton sand

Peoples sand

Okesa, Torpedo, and Clem Creek sand zone....... 307

Bigheart sand ... 307

T. 23 N., R. 7 E. 307

Structure and development.

Upper Bug Creek dome..... 309

Middle Bug Creek dome._._. 310

Lower Bug Creek dome.

Dome in E1/2 sec. 36.... 312

Sycamore dome _... 312

Oil pools in the Burbank sand. 313

T. 24 N., R. 7 E._.

Structure and development._. 314

Naval Reserve field

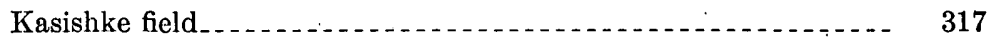

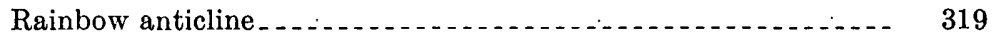

Northeast quarter of the township.

\section{ILLUSTRATION}

Plate 9. Map of Tps. 23 and 24 N., R. 7 E., Osage County; Okla_... In pocket 



\title{
SUBSURFACE GEOLOGY AND OIL AND GAS RESOURCES OF OSAGE COUNTY, OKLAHOMA
}

\author{
Part 9. Townships 23 and 24 North, Range 7 East
}

\author{
By N. W. Bass, W. R. Dillard, L. E. Kennedy, and H. B. Goodrioh
}

\begin{abstract}
Tps. 23 and 24 N., R. 7 E., whose subsurface geology and oil and gas resources are described in this report, lie in south-western Osage County. The southeast corner of the area made up of these townships is 6 miles west of Hominy, and the northeast corner is 9 miles southwest of Pawhuska. The principal oil and gas fields are the large Naval Reserve fleld, in T. 24 N., R. 7 E., and several small fields in the eastern part of T. 23 N., R. 7 E. These producing areas lie on the northwestern margin of a large area in eastern Osage County that contains many oil 'and gas fields. Most of the oil and gas in T. 24 N., R. 7 E., is produced from the Burbank sand at a depth of about 2,500 feet; and most of the oil and gas in T. 23 N., R. 7 E., is produced from Ordovician beds at a depth of about 2,850 feet. In addition to these zones, seven others yield oil or gas in a few wells.

The regional dip of the rocks in the two townships is westward at an average rate of 40 feet to the mile, as measured on the top of the Oswego lime. The dip is relatively uniform in the western two-thirds of the area, but in the eastern third it is interrupted by several prominent domes and anticlines. Each of the domes and anticlines covers an area of less than two square miles and has a structural relief on the top of the Oswego lime of less than 100 feet. The strueture of the buried rocks is similar to that in the exposed rocks, although the dips in the buried rocks are steeper than those in the exposed rocks and the crests of the domes and anticlines in the buried rocks do not lie directly beneath the corresponding crests in the exposed rocks.

The investigation has shown that there are a few localities prospectively valuable for oil and gas in Tps. 23 and 24 N., R. 7 E., that have not been tested; that several producing pools can be extended by the drilling of additional wells; that the practice of treating limy reservoir beds with acid to induce increased yields of oil and gas should be continued; that additional oil may be produced in the Naval Reserve field by the continued repressuring of the reservoir sand with gas; and that additional oil may eventually be produced in the area by flooding the reservoir sands, particularly the Burbank sand, with water.
\end{abstract}

\section{INTRODUCTION}

The subsurface geologic features, the oil- and gas-bearing beds, and the areas that are now producing oil and gas and those that 
are favorable for prospecting in Tps. 23 and 24 N., R. 7 E., Osage County, Okla., are described in this report, which is the ninth of a series of reports on parts of Osage County. The structure of the buried rocks, the oil and gas wells, the abandoned wells and dry holes, and the ownership of leases are shown on the accompanying map (pl. 9). The oil- or gas-bearing beds in producing and abandoned wells and the deepest rocks penetrated in dry holes are shown on the map by colors on the black well symbols. Wells that produced oil or gas from shallow depths and were drilled deeper to test older beds are indicated by special symbols.

All rocks penetrated by the drill are shown graphically in a generalized columnar section on plate 9 . The beds that produce oil or gas are indicated by colors on the columnar section, the colors corresponding to those on the well symbols on the structure contour map. The names of the oil- or gas-producing beds in each township are shown also in the following table.

Oil-and gas-producing beds in Tps. 23 and $24 N ., R . \gamma$ E., Osage County, Okla.

\begin{tabular}{l|l||l|l}
\hline \multicolumn{1}{c|}{ T. 23 N., R. 7 E. } & \multicolumn{1}{|c|}{ T. 24 N., R.7 E. } & T. 23 N., R.7 E. & T. 24 N., R.7 E. \\
\hline $\begin{array}{l}\text { Okesa sand. } \\
\begin{array}{l}\text { Peoples sand. } \\
\text { Layton sand. }\end{array}\end{array}$ & $\begin{array}{l}\text { Bigheart sand. } \\
\text { Torpedo sand. }\end{array}$ & $\begin{array}{l}\text { Skinner sand. } \\
\text { Burbank sand. } \\
\text { Simpson formation and } \\
\text { Siliceous lime. }\end{array}$ & $\begin{array}{l}\text { Burbank sand. } \\
\text { Mississippi lime. } \\
\text { Simpson formation ana } \\
\text { Siliceous lime. }\end{array}$ \\
\hline
\end{tabular}

All the rocks exposed in Tps. 23 and 24 N., R. 7 E., belong to the Pawhuska and Buck Creek formations. Their distribution is shown on the State geologic map by Miser.1

The distribution, character, and structure of many key beds have been described by Bowen, Roundy, Ross, and Reeves, ${ }^{2}$ and the structure contour maps prepared by them were used extensively in drawing the structure contour lines on plate 9 , particularly in areas for which there are few or no specific data on the attitude of the buried rocks.

\section{OIL- AND GAS-PRODUCING BEDS}

Oil or gas has been produced in Tps. 23 and 24 N., R. 7 E., from 10 zones, ranging from the uppermost part of the Siliceous lime of the Ordovician system upward to the Bigheart sand in the Nelagoney formation of the Pennsylvanian series. The depth to the oil- or gas-bearing beds ranges from 700 feet to 3,000 feet. The Burbank sand has produced oil in more wells than all the

I Miser, H. D., Geologic map of Oklahoma, U. S. Geol. Survey, 1926.

2 Bowen, C. F., Roundy, P. V., Ross, C. S., and Reeves, Frank, in White, Davld and others, Structure and oil and gas resources of the Osage Reservation, Okla.: U. S. Geol. Survey Bull. 686, pp. 137-145, 279-289, 291-295, anl pls. 23 and 43, 1922. 
other zones combined; the main producing area in this sand is in. T. $24 \mathrm{~N}$., R. 7 E. The Siliceous lime is the principal producing: zone in T. 23 N., R. 7 E. The oil- and gas-producing rocks aredescribed briefly from the oldest to the youngest on the following pages.

\section{SILICEOUS LIME AND SIMPSON FORMATION}

Only the uppermost 350 feet of the Siliceous lime has been penetrated by the drill in Tps. 23 and 24 N., R. 7 E. Oil is found in the uppermost 5 to 40 feet of the Siliceous lime on several domes and anticlines, and the oil-bearing beds and other beds closely associated with them consist of finely crystalline brown to white dolomite that commonly contains chert.

The Simpson formation, which unconformably overlies the Siliceous lime, is about 100 to 125 feet thick. According to Luther White, ${ }^{3}$ the sandstone making up the lower part of the Simpson is equivalent to the Burgen sandstone, and the upper part, which consists of interbedded green shale, sandy shale, and sandstone, is equivalent to the Tyner formation. The logs record some oil in both the Tyner and Burgen, but most of the oil from Ordovician beds in these two townships is derived from the uppermost beds of the Siliceous lime.

\section{MISSISSIPPI LIME}

A small amount of oil has been produced from the Mississippi lime in a few wells. This lime is about 225 feet thick. It consists mainly of limestone and chert, and the oil occurs in porous chert beds at or near the top of the lime. The absence of large pools in this bed is noteworthy, because the two townships lie in the projection of a broad northeastwardly-trending belt in central and northeastern Osage County that contains many oil pools in the Mississippi lime.

\section{BURBANK SAND}

The Burbank sand, the main producing bed in the Naval Reserve field in T. 24 N., R. 7 E., occurs in the lower part of the Cherokee shale-about 60 feet above the base of the formation. In most localities it lies immediately below the Pink lime or is separated from that lime by a thin bed of shale. The sand is present in only parts of the two townships, mainly in T. 24 N., R. 7 E. It occurs characteristically in elongated lenses, which are surrounded by sandy shale or shale, and the limits of the oil pools in the sand are determined

${ }^{3}$ White, L. H., Subsurface distribution and correlation of the pre-Chattanooga ("Wilcox" kand) series of northeastern Oklahoma: Oklahoma Geol. Survey Bull. 40, vol, 1, pp. 24 (table), 29-32, 1928. 
mainly by the pinching out of the sand bodies. The reservoir sand of the Naval Reserve field is a large lens of Burbank sand.

The: Burbank sand, as shown by a microscopic study of samples from several wells by Constance Leatherock,${ }^{4}$ is composed largely of quartz grains, although there are minor amounts of mica and feldspar and traces of other minerals. Very small concretions of siderite also occur, particularly in the sandy-shale phases. The sand is largely made up of fine to very fine grains-1/16 to $1 / 4$ millimeter in diameter- and contains as much as 20 to 40 percent of silt. Occasional grains, however, are large enough to be classed as coarse or even very coarse.

The logs of several wells in the southeastern part and of a few in the central part of T. 23 N., R. 7 E., record a thin sand that is here described as a lower bed of the Burbank sand, though it may be equivalent to the uppermost part of the Bartlesville sand. The sand is about 80 feet below the Pink lime and is separated from the Mississippi lime by a bed of shale 40 to 90 feet thick.

\section{SKINNER SAND}

The $\operatorname{logs}$ of a few wells record sand from 5 to 25 feet thick at the stratigraphic horizon of the Skinner sand in the Cherokee shale, and a few wells in T. 23 N., R. 7 E., produce oil from the sand. The horizon of the sand is occupied by shale in most places.

\section{LAYTON SAND}

The Layton sand is a zone 50 to 100 feet thick in the upper part of the Coffeyville formation and contains one or more beds of sandstone in most localities. It yields water in most wells but produced oil for several months in two wells in secs. 12 and 13, T. 23 N., R. 7 E.

\section{PEOPLES SAND}

The logs of wells record sandstone and shale beds and a few thin beds of limestone in a zone about 150 feet thick that appears to occupy the position of the Peoples sand, Dewey limestone, and Mussellem sand. The identification of individual beds in this sequence from the logs is impossible, but the zone as a whole appears to be persistent. Beds of sand in the lower part of the sequence are here tentatively designated the Peoples sand, and beds of sand in the upper part are designated the Mussellem sand. The Peoples sand produced oil at a small daily rate in well 18 in the $\mathrm{SE} 1 / 4$ sec. $26, \mathrm{~T}$. 23 N., R. 7 E.

\footnotetext{
${ }^{4}$ Leatherock, Constance, Physical characteristics of Bartlesville and Burbank sands in. northeastern Oklahoma and southeastern Kansas: Am. Assoc. Petroleum Geologists Bull., vol. 21, No. 2, pp. 254-258, 1937.
} 


\section{OKESA, TORPEDO, AND CLEM CREEK SAND ZONE}

A sequence of sandstone and shale beds and a few thin beds of limestone, here tentatively referred to as the Okesa, Torpedo, and Ciem Creek sand zone, occupies an interval, about 150 to 175 feet thick, immedately above the middle of the Ochelata formation, Single beds in the zone cannot be identified in the logs from well to well, but the zone is persistent. Four wells near the middle of sec. 22 , T. 24 N., R. 7 E., produce gas from sand near the middle of the zone, and one well in the NE $1 / 4 \mathrm{SE} 1 / 4$ sec. 36, T. 23 N., R. 7 E., produces gas from sand near the top of the zone.

\section{BIGHEART SAND}

Several wells in sec. 24, T. 24 N., R. 7 E., produce oil from sand that appears to occupy the position of the Bigheart sand. The oil is found in several thin beds of sand that are interbedded with shale, limestone, and red rock. The producing wells have small daily/ yields, but the shallow depth of the sand-700 feet-makes the outlay for drilling reasonably small.

\section{T. 23 N., R. 7 E.}

T. 23 N., R. 7 E., is in southwestern Osage County. Its southeast corner is about 7 miles northwest of Cleveland, and its northeast corner is 13 miles southwest of Pawhuska.

A total of $3,896,413$ barrels of oil and an unknown quantity of gas had been produced in the township up to December 31, 1938. Nearly all the oil was produced from five small areas in which the rocks are arched into domes. The total productive area is estimated to be 800 acres, and the average yield of oil to the acre to December 31,1938 , was about 4,900 barrels. The oil and gas are derived from six zones, which lie at depths ranging from 950 to 2,950 feet, but most of the production is from beds of Ordovician age at a depth of 2,700 to 2,950 feet-the Simpson formation or the uppermost part of the Siliceous lime. The less productive zones are the lower bed of the Burbank sand, which has yielded oil in five wells; an upper bed of the Burbank; which has yielded oil in one well; the Skinner sand, which has yielded oil in seven wells; the Layton sand, which yielded oil for several months in two wells; the Peoples sand, which has yielded a small amount of oil in one well; and the Okesa sand, which has yielded gas in one well. Although shows of oil and gas were found in the Mississippi lime in many wells, neither has been produced from this lime. The apparent absence of commercial oil and gas pools in the Mississippi lime is noteworthy, because the township lies in a broad northeastward-trending belt in central and northeastern Osage County that contains many 
pools in this lime, and only a few miles east and northeast of the township oil pools are present in the lime.

About 100 wells have been drilled in T. 23 N., R. 7 E., of which 78 produced oil, 1 produced gas, and 21 proved to be dry holes. The first drilling was done in 1919, when a dry hole in the southeast corner of sec. 8 tested the Mississippi lime to a total depth of 2,874 feet. Another dry hole, drilled in 1.919 in the NE1/4 sec. 36, reached Ordovician rocks, and during the same year a well in the NW1/4. sec. 23 discovered oil in the Ordovician at a depth of 2,755 to 2,829 feet. At about the same time oil was discovered in the Skinner sand in the $\mathrm{NE} 1 / 4$ sec. 35 .

Development of the oil pools on the Lower Bug Creek and Middle Bug Creek domes took place mainly in 1920 and 1921 and of the oil pool on the Upper Bug Creek dome mainly in 1920 and 1930. The two oil wells in secs. 9 and 16 on the Sycamore dome were drilled in 1928 and 1929. The drill reached deepest in the township in the dry hole in the NW1/4 SE1/4 sec. 19, where it went to a depth of 3,221 feet and was stopped in the Siliceous lime.

The subsurface investigation of T. $23 \mathrm{~N}$., R. 7 E., was made in 1935 and 1936 by W. R. Dillard, L. E. Kennedy, and N. W. Bass, and in 1939 by $\mathrm{H}$. B. Goodrich and N. W. Bass. The data on production were compiled in 1939 by M. D. Meribel of the Osage Indian Agency from records on file at the agency.

\section{STRUCTURE AND DEVELOPMENT}

The regional dip of the rocks in T. 23 N., R. 7 E., is westward at the rate of 40 feet to the mile, as measured on the top of the Oswego lime. In the eastern third of the township the regional dip is interrupted by three prominent domes and a relatively deep structural basin. The available data indicate that the rocks in the western two-thirds have a relatively uniform westward dip except on the Sycamore dome in secs. 9, 10, 15, and 16. The data on the subsurface rocks in this part of the township are limited, however, because only a few wells have been drilled; the drilling of new wells may reveal the presence of additional domes.

The surface rocks in secs. 15,16 , and 9 are cut by a normal fault ${ }^{5}$ that trends northwestward for a short distance and then swings northeastward. The maximum vertical displacement of the rocks along the fault is 90 feet in the $\mathrm{SE} 1 / 4 \mathrm{SE} 1 / 4 \mathrm{sec} .9$. The two producing wells in secs. 9 and 16 are on the upthrow side and west of the fault. The available data are insufficient to determine to what depth the buried rocks are displaced along the fault.

\footnotetext{
${ }^{5}$ Bowen, C. F., Roundy, P. V.; Ross, C. S., and Reeves, Frank, in White, David, and others, Structure and oil and gas resources of the Osage Reservation, Okla.: U. S. Geol. Survey Bull. 686, pl. 43, 1922.
} 


\section{UPPER BUG CREEK DOME}

The Upper Bug Creek dome, whose crest is in the SW1/4 sec. 12, occupies parts of secs. 11 to 14 . The dome has a structural closure: of 70 feet on the top of the Oswego lime, which is more than twice" the amount of closure in the surface rocks. It is noteworthy that; the crest of the dome on the Oswego lime lies directly under the crest of the dome in the surface beds, although in this part of Oklahoma the subsurface crests of most domes and anticlines do not lie directly beneath the crests in the surface rocks.

Several wells on the Upper. Bug Creek dome produce oil from. Ordovician rocks. Some of the oil, as indicated by the drillers' logs, is derived from the Simpson formation, but most of it comes from the uppermost few feet of the Siliceous lime, which is encountered at a depth of about 2,875 feet. The initial daily yields of the wells range from 10 to 2,300 barrels; three of the wells produced initially more than 1,000 barrels a day each. Four wells were given acid treatment after producing for several years, and two of them responded with greatly increased yields. The most productive wells are near the crest of the dome, and the largest total production from any tract in the field has come from the SW1/4 sec. 12 .

Well 1 in the southeast corner of NW1/4 sec. 12, which was drilled in 1933, produced oil for about nine months from the Layton sand at a depth of 1,620 feet. The initial daily yield of the well from this sand was 65 barrels. The well was then deepened into the Ordovician rocks, from which it produced at the rate of 210 barrels a day. Well 1 in the SE1/4 sec. 13, low on the southeast flank of the dome, tested the Ordovician rocks and was plugged back to a depth of 1,670 feet, at which it produced from the Layton sand at an initial daily rate of 40 barrels. The well was abandoned, however, after producing for two months.

It appears probable that other wells drilled to the Siliceous lime in the SW1/4 and the $\mathrm{W}^{1 / 2} \mathrm{~W}^{1} / 2 \mathrm{SE}^{1} / 4$ sec. 12 , would prove profitable; and if they are drilled it would seem advisable to treat the Siliceous lime reservoir beds with acid.

Oil produced from the Upper Bug Creek dome

\begin{tabular}{|c|c|c|}
\hline Tract & $\begin{array}{l}\text { Date of } \\
\text { frrst pro- } \\
\text { duction }\end{array}$ & $\begin{array}{l}\text { Production } \\
\text { to end of } 1938 \\
\text { (barrels) }\end{array}$ \\
\hline \multirow[t]{2}{*}{$\begin{array}{l}\text { NW1/4 sec. } 12 \\
\text { SW1/4 sec. } 12 \\
\text { SE1/4ec. } 12 \\
\text { NE1/4 sec. } 13 \\
\text { NW1/4 sec. } 13 \\
\text { NE1/4 sec. } 14\end{array}$} & $\begin{array}{l}1933 \\
1932 \\
1933 \\
1933 \\
1932 \\
1933\end{array}$ & $\begin{array}{r}109,331 \\
295,353 \\
117,679 \\
142,382 \\
241,070 \\
24,722\end{array}$ \\
\hline & & 930,537 \\
\hline
\end{tabular}


The total amount of oil produced from the Upper Bug Creek dome as compiled from records on file at the Osage Indian Agency, is shown in the preceding table.

If it is assumed that each well in the pool drains 10 acres, the average amount produced to the acre to the end of December 1938 was 8,450 barrels.

\section{MIDDLE BUG CREEK DOME}

The Middle Bug Creek dome lies mainly in sec. 23. Its structural closure is about 40 feet on the top of the Oswego lime and about 20 feet in the exposed rocks. The crest of the dome in the Oswego lime lies directly beneath the crest in the surface beds. Oil has been produced from Ordovician rocks in several wells, from the Burbank sand in two wells, and from the Skinner sand in two wells. The drillers' logs indicate that the main oil-bearing zone in the Ordovician rocks is the Burgen sand, in the lower part of the Simpson formation. The logs indicate, also, that the oil in well 2 in the northeast corner sec. 23 is derived from the main bed of Burbank sand and that the oil in well 5 in the southwest corner of the NW1/4 sec. 23 is derived from a lower bed of the Burbank sand.

The initial daily yield of all the wells on the dome ranged from 25 to 2,000 barrels each, but the initial daily yield of half of them was about 300 barrels each. All but two of the wells producing from Ordovician rocks have been abandoned. Wells on or near the crest of the dome have yielded the largest amounts of oil. The initial daily yields of the two wells obtaining oil from the Burbank sand were 50 and 75 barrels, respectively, and the initial daily yields of the two wells producing from the Skinner sand were 40 and 200 barrels, respectively. The total amount of oil produced from the Middle Bug Creek dome, as compiled from records on file at the Osage Indian Agency, is shown in the following table:

Oil produced from the Middle Bug Creek dome

\begin{tabular}{|c|c|c|c|}
\hline Tract & $\begin{array}{l}\text { Date of } \\
\text { first pro- } \\
\text { duction }\end{array}$ & $\begin{array}{c}\text { Production } \\
\text { to end of } \\
1938 \text { (barrels) }\end{array}$ & Remarks \\
\hline $\begin{array}{l}\text { NE1/4 sec. } 22 \\
\text { SE1/4 sec. } 22 \\
\text { NE1/4 sec. } 23 \\
\text { NW1/4 sec. } 23 \\
\text { SW11/4 sec. } 23 \\
\text { SE1/4 sec. } 23\end{array}$ & \multirow[t]{2}{*}{$\begin{array}{l}1921 \\
1921 \\
1920 \\
1919 \\
1920 \\
1920\end{array}$} & $\begin{array}{r}60,768 \\
29,732 \\
64,129 \\
232,013 \\
248,065 \\
51,894\end{array}$ & \multirow[t]{2}{*}{ Abandoned Aug. 20, 1931.} \\
\hline & & 686,601 & \\
\hline
\end{tabular}

If it is assumed that the wells in the field have drained oil from a total area of 135 acres, the average production to December 31, 1938, was about 7,000 barrels to the acre. 


\section{LOWER BUG CREEK DOME}

The Lower Bug Creek dome occupies parts of secs. 25, 26, 35 and 36. The highest point on the top of the Oswego lime is near the southwest corner of sec. 25 (see pl. 9), a few hundred feet northwest of the crest of the dome in the exposed rocks. ${ }^{6}$ The structural closure on the top of the Oswego lime is somewhat more than 40 feet and in the exposed rocks is slightly more than 10 feet.

The oil on the Lower Bug Creek dome comes from the Skinner and Peoples sands and from the Simpson formation or the Siliceous lime. Most of the wells produce from the Simpson formation or the Siliceous lime at a depth of about 2,800 feet; and, although the available data are too meager to determine whether the oil-bearing beds in most wells are in the Simpson formation or in the Siliceous lime, the main reservoir bed, as shown by the drillers' logs, occurs. in the Simpson formation.

The initial daily yields of the wells producing from the Simpson formation or the Siliceous lime range from 10 to 420 barrels. Seven wells had an initial daily yield of more than 2,000 barrels each, and the initial daily yield of all except eight of the wells exceeded 100 barrels each. The initial daily yield of wells producing from the Skinner sand was less than 50 barrels each. Two wells on the northeast flank of the dome produced oil from a lower bed of the Burbank sand. The initial daily yields of these wells were 40 and 70 barrels, respectively. Well 18 in the $\mathrm{SE} 1 / 4$ sec. 26 , which produced oil from the Peoples sand at a depth of 1,400 feet, had an initial daily yield of 10 barrels. The total amount of oil produced from the Lower Bug Creek dome, as compiled from the records on file at the Osage Agency, is shown in the following table:

Oil produced from the Lower Bug Creek dome

\begin{tabular}{|c|c|c|c|}
\hline Tract & $\begin{array}{l}\text { Date of } \\
\text { first pro- } \\
\text { duction }\end{array}$ & $\begin{array}{c}\text { Production } \\
\text { to end of } \\
1938 \text { (barrels) }\end{array}$ & Remarks. \\
\hline \multirow[t]{2}{*}{$\begin{array}{l}\text { NW1/4 sec. } 25 \\
\text { SW1/4 sec. } 25 \\
\text { NE1/4 sec. } 26 \\
\text { NW1/4 sec. } 26 \\
\text { SW1/4 sec. } 26 \\
\text { SE1/4 sec. } 26 \\
\text { NE1/4 sec. } 35 \\
\text { NW1/4 sec. } 35 \\
\text { NW1/4 sec. } 36\end{array}$} & \multirow[t]{2}{*}{$\begin{array}{l}1924 \\
1921 \\
1921 \\
1920 \\
1920 \\
1920 \\
1919 \\
1920 \\
1920\end{array}$} & $\begin{array}{r}217 \\
139,487 \\
57,037 \\
2,287 \\
42,135 \\
903,173 \\
444,870 \\
6,331 \\
171,056 \\
\end{array}$ & \multirow[t]{2}{*}{$\begin{array}{l}\text { Abandoned Dec. 8, } 1925 . \\
\text { Abandoned June 18, } 1925 . \\
\text { Abandoned Jan. 4, } 1924 . \\
\text { Abandoned June 14, } 1934 . \\
\text { Abandoned Jan. 23, } 1924 . \\
\text { Abandoned Sept. 13, } 1934 .\end{array}$} \\
\hline & & $1,766,593$ & \\
\hline
\end{tabular}

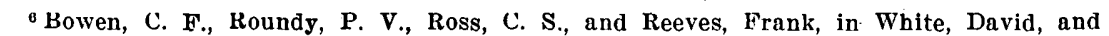
others, Structure and oil and gas resources of the Osage Reservation, Okla.: U. S. Geol. Survey Bull. 686, pl. 43, 1922. 
If it assumed that the producing wells drained oil from a total area of 320 acres, the average production to December 31, 1938, was 5,520. barrels to the acre.

\section{DOME IN E1/2 SEC. 36}

The small dome whose crest is in the SE $1 / 4 \mathrm{NE} 1 / 4$ sec. 36 represents the southeastern extension of the Lower Bug Creek dome. The dome extends into sec. 31 , T. 23 N., R. 8 E. Five wells in sec. 36 on the dome have yielded oil from Ordovician rocks, two wells produce oil from a lower bed of the Burbank sand, and one well produces gas from the Okesa sand. The oil-bearing bed in the Ordovician probably lies in the Burgen sand of the Simpson formation, but some oil may be derived from the uppermost beds of the Siliceous lime: The initial daily yields of wells producing from the Ordovician rocks range from 18 to 165 barrels each. The initial daily yields of tho two wells producing from the lower bed of the Burbank sand were 20 barrels each. A total of 147,851 barrels of oil had been produced from the NE1/4 sec. 36 and a total of 89,479 barrels from the SE $1 / 4 \mathrm{sec}$. 36 up to December 31, 1938. The initial daily yield of the gas well producing from the Okesa sand was $2,750,000$ cubic feet.

It is probable that additional wells in the $\mathrm{S} 1 / 2 \mathrm{NE} 1 / 4$ and $\mathrm{SE} 1 / 4$ sec. 36 would yield oil from Ordovician rocks, which lie at a depth of about 2,900 feet. The oil-bearing beds probably contain sufficient limy material to make acid treatment advisable.

\section{SYCAMORE DOME}

Two wells in the SE1/4 sec. 9 and the NE1/4 sec. 16 produce oil from the uppermost beds of the Siliceous lime or from the Simpson formation. The drillers' logs indicate that in each well the drill penetrated the topmost 2 or 3 feet of the Siliceous line and that at least some oil is derived from the Simpson formation. The wells have produced for 11 years; during that time the total production from the well in the SE1/4 sec. 9 has been 189,704 barrels, and the total production from the well in the $\mathrm{NE}^{1} / 4$ sec. 16 has been 85,645 barrels. If it is assumed that each well drains oil from an area of 10 acres, the average yield to the acre to December 31, 1938, was 13,767 barrels. Very little information is available concerning the structure of the rocks in the vicinity of the producing wells. The surface rocks form a southwestward-plunging anticlinical nose that is interrupted in the $\mathrm{E} 1 / 2$ sec. 9 and in the $\mathrm{NE} 1 / 4$ sec. 16 by a fault; ${ }^{7}$ but the information is insufficient to determine to what depth the fault displaces the buried rocks. Although the positions of the

\footnotetext{
'Bowen, C. F., Roundy, P. V., Ross, C. S., and Reeves, Frank, in White, David, and others, Structure and oil and gas resources of the Osage Reservation, Okla.: U. S. Geol. Survey Bull. 686, pl. 43, 1922.
} 
contours shown in this area on plate 9 are hypothetical, they suggest. that additional productive wells may be obtained east of the present producing wells.

\section{OIY POOLS IN THE BURBANK SAND}

The Naval Reserve oil pool which occurs in a lens-shaped body of Burbank sand that is elongated southward, is in T. 24 N., R. 7 E., and its south end is less than a mile north of the north boundary of T. 23 N., R. 7 E. In general, the oil-bearing lenses of Burbank sand lie approximately end to end in narrow belts, and the individual lenses in the belt are separated by gaps containing no sand. ${ }^{8}$ If these features prevail here, it is reasonable to expect the presence of lens-shaped bodies of oil-bearing Burbank sand in a broad belt extending southward through the middle of T. $23 \mathrm{~N}$., R. $7 \mathrm{E}$. The $\log$ of the dry hole in the NE $1 / 4 \mathrm{SE} 1 / 4 \mathrm{sec} .3$ recorded shale at the horizon of the Burbank sand. It is reported that the dry hole in sec. 5 found a show of oil in the Burbank sand, 8 feet thick, but the log records a hole full of water in the sand. The log of the 'dry hole in the SE1/4 NE1/4 sec. 6 records sandy shale and broken sand at the horizon of the Burbank. Shale is recorded at the horizon of the sand in the log of the dry hole in the SE1/4 SE $1 / 4$ sec. 8 ; and fine silty sand and shale are recorded at that horizon in the logs of the wells in secs. 9 and 16. Experience in prospecting for pools in the Burbank sand in eastern Kansas and in northeastern Oklahoma has proved that dry holes such as those described above condemn only small tracts surrounding the wells. Therefore it appears that most of a broad belt extending southward through the middle of T. 23 N., R. 7 E., remains prospectively valuable for oil in the Burbank sand.

\section{T. 24 N., R. 7 E.}

T. 24 N., R. $7 \mathrm{E}$ is in southwestern Osage County. Its southeast corner is about 36 miles northwest of Tulsa, and its northeast corner is 9 miles southwest of Pawhuska. Three oil- and gas-producing areas, one of which is the Naval Reserve field, lie in this township.

Oil or gas has been produced from five zones, which lie at depths ranging from 700 to 2,985 feet. Of these, the Burbank sand, which lies at a depth of 2,400 to 2,600 feet, is the most productive, having yielded more than 90 percent of the total yield of oil from the township-14,000,000 barrels. The Simpson formation or the uppermost beds of the Siliceous lime, which lie at a depth of about 2,850 feet, have yielded oil in 13 wells, and the Mississippi lime has yielded oil

\footnotetext{
${ }^{8}$ Bass, N. W., Leatherock, Constance, Dillard, W. R., and Kennedy, L. E., Origin and distribution of Bartlesville and Burbank shoestring oil sands in parts of Oklahoma and Kansas: Am. Assoc. Petroleum Geologists Bull., vol. 21, No. 1, pp. 31, 40-43, 1937.
} 
in 6 wells. The Torpedo sand, which lies at a depth of about 1,185 feet, has yielded gas in 4 wells. The Bigheart sand; which lies at a depth of 700 feet, has yielded oil in several wells in sec. 24 .

In all, almost 350 wells have been drilled in T. 24 N., R. 7 E, of which, 286 have produced oil, and of these 9 have been abandoned. Included in the total number are 21 wells that are used for injecting gas into the sand and 3 wells that are used for the disposal of salt water. Eleven wells, three of which have been abandoned, produced gas. Only 24 dry holes have been drilled in the township.

Oil development began early in 1928 in sec. 22, on the North Hominy Creek anticline on the eastern margin of the Naval Reserve field. Gas was obtained that year at a shallow depth, and in 1929 oil and gas were found in the Burbank sand in secs. 21 and 22. Most of the wells in the Naval Reserve field were drilled from 1933 to 1938. The latest attempt to extend the field was made in 1939 by the drilling of a well in the southeast corner of the $\mathrm{NW} 1 / 4$ sec. 17 , on the west margin of the field; a small amount of oil was found in the Burbank sand, but in March 1939 the well was abandoned after producing about 100 barrels.

Production of oil from Ordovician beds and from the Bigheart sand in the NE $1 / 4$ sec. 24 was begun in 1932 ; development there is still in progress. Five producing oil wells were drilled during 1933 and 1934 in a small area in secs. 25 and 36 ; the productive beds there are in the Simpson formation or the Siliceous lime, and in the Mississippi lime. Well 1 in the NW1/4 sec. 12, which was drilled in 1933, produced some oil from the Siliceous lime but was abandoned in 1937. In well $1-\mathrm{A}$, in the $\mathrm{SW} 1 / 4$ sec. 16 , oil was produced for three days from a sand in the Nelagoney formation that may be equivalent to the Cheshewalla sand; after a small amount of oil was obtained the well was converted into a salt-water disposal well. The Cheshewalla sand, which lies a short interval above the Bigheart sand, is not included in the table of oil- or gas-producing beds because the small amount of oil obtained from it is regarded only as a show.

The subsurface investigation of T. 24 N., R. 7. E., was made in 1935 mainly by W. R. Dillard, L. E. Kennedy, and N. W. Bass and in 1939 by H. B. Goodrich. The data on production were compiled in 1.939 by H. B. Goodrich from records on file at the Osage Indian Agency.

\section{STRUCTURE AND DEVELOPMENT}

The regional dip of the rocks in T. 24 N., R. 7 E., is westward at the rate of about 40 feet to the mile as measured on the top of the Oswego lime. The regional dip is interrupted by several folds, the most prominent of which are the North Hominy Creek anticline, whose crest is in sec. 22, the dome in sec. 24, the Rainbow anticline in 
secs. 25 and 36 , and the deep synclines that lie southeast and northeast of the Naval Reserve field. These folds are expressed in both the buried rocks and the exposed rocks, but the dips in the buried rocks are steeper than those in the exposed rocks and the crests of the domes and anticlines in the buried rocks do not lie directly under the crests in the surface beds.

\section{NAVAL RESERVE FIELD}

The Naval Reserve field occupies an elongated area in the central part of the township. The field is $4 \frac{1}{2}$ miles long and its greatest width is 2 miles. A total of 287 wells have been drilled in the field, of which 266 produced oil, 10 produced gas, and 11 proved to be dry holes. Five oil wells and one gas well have been abandoned, and 18 wells widely distributed through the field are used to inject gas into the Burbank reservoir sand. The oil in most wells is derived from the Burbank sand. Five wells near the eastern margin of the field produce gas from the Burbank sand, and their initial daily yields ranged from $10,000,000$ to $32,000,000$ cubic feet each. Six wells in sec. 22 produced oil from the Simpson formation or the Siliceous: lime. One well in the $\mathrm{SW} 1 / 4$ sec. 15 , produces oil at a small daily rate from the Mississippi lime. The Torpedo sand yielded gas in sec. 22 in four wells, one of which has been abandoned.

In most of the Naval Reserve field the rocks dip westward at a relatively uniform rate except for local flexures such as the syncline in the $\mathrm{N} 1 / 2$ sec. 28 and the dome in the $\mathrm{NE} 1 / 4$ sec. 21 . The most prominent structural feature is the North Hominy Creek auticline on the eastern margin of the field. The structural closure on the top of the Oswego lime on this anticline is about 80 feet, and the closure in the exposed rocks is about 30 feet. Morover, the crest of the anticline on the Oswego lime lies about 1,500 feet southwest of its crest in the surface beds:

Well 2 in the SW1/4 sec. 22 was the first productive oil well in the Naval Reserve field. It was completed February 23, 1928, when it yielded oil at the rate of 360 barrels a day from the Siliceous lime at a depth of 2,910 feet. The well was drilled near the crest of the North Hominy Creek anticline, which had been mapped by Bowen ${ }^{9}$ many years before the drilling of the well and had been recommended by him as the most favorable site for the prospecting of an area embracing several townships in western Osage County. During 1928 two additional wells that were drilled into the Siliceous lime produced initially 200 and 810 barrels of oil a day, respectively. Four wells near the center of sec. 22 yielded gas from the Torpedo sand

\footnotetext{
- Bowen, C. F., in White, David, and others, Structure and oil and gas resources of the Osage Reservation, Okla. : U. S. Geol. Survey Bull. 686, p. 145, and pl. 23, 1922.
} 
at a depth of a little less than 1,200 feet; the initial daily yields of these wells ranged from $6,000,000$ to $17,500,000$ cubic feet each. The first gas produced from the Burbank sand was found in January 1929 in well 2 in the $\mathrm{NW}_{1 / 4}$ sec. 22 , which had been drilled to a total depth of 3,087 feet and then was plunged back to a depth of 2,504 feet; the initial daily yield of the well was $11,000,000$ cubic feet. Well $6-\mathrm{B}$ in the $\mathrm{NW} 1 / 4$ sec. 22 produced initially $32,000,000$ cubic feet of gas a day from the Burbank sand.

Well 1 in the SE1/4 NE $1 / 4$ sec. 21, which was completed in May 1939, was the first well in the Naval Reserve field to produce oil from the Burbank sand; its initial daily yield was 112 barrels, and development spread rapidly westward, northwestward, and southwestward from it. The well is on the west flank of the North Hominy Creek anticline, about 133 feet lower structurally than the crest as mapped on the top of the Oswego lime. But the attitude of the buried rocks is not the main factor in the accumulation of oil in the Burbank sand body of the Naval Reserve field. The well logs show that the reservoir sand pinches out relatively abruptly on both the east and west margins of the field. The sand body is, therefore, a lensshaped body, and is similar to other shoestring oil-bearing sand bodies in western Osage County, Okla., and Cowley, Butler, and Greenwood Counties, Kans. The oil-producing area extends across the minor structural elevations and depressions, and several of the most productive parts of the field are found at structurally low points. For example, the SW1/4 sec. 21 , in which the rocks are structurally low, has had the largest yield to the acre of all quarter sections in the field-about 18,000 barrels to December 31, 1938. Most wells produce no water, though water has been found in the Burbank sand in several wells in the western part of the field, where it occurs at depths ranging from 1,645 to 1,677 feet below sea level. The behavior of producing wells indicates that the water is held under very small hydrostatic pressure and therefore does not act as a drive on the oil in the sand body.

Initial daily yields of wells producing from the Burbank sand have ranged from 11 to 2,205 barrels each; the initial daily yield of many wells has been more than 1,000 barrels each. To December 31,1938 , the total amount of oil recovered to the acre in the Naval Reserve field ranged from 1,140 barrels from one tract in sec. 9, to 18,000 barrels, from a tract estimated at 70 acres in the $\mathrm{SW}^{1 / 4}$ sec. 21.

The margins of the Naval Reserve pool in the Burbank sand have already been defined in several places, but in other places additional wells should be drilled. It is probable that new wells could be obtained in the $\mathrm{W}^{1} 1 / 2$ sec. 9 , the $\mathrm{SW} 1 / 4$ sec. 4 , the $\mathrm{S} 1 / 2$ sec. 17 , the 
$\mathrm{NE} 1 / 4$ sec. 20 , the SW $1 / 4$ sec. 15 , the W1/2 sec. 27 , the NW1/4 sec. 34 , the $\mathrm{W} 1 / 2$ sec. 28 , and the $\mathrm{N} 1 / 2$ sec. 33. A few additional wells might be obtained, also, in the SW1/4 sec. 22 from the Siliceous lime on the crest of the South Hominy Creek anticline, and acidization of the calcareous reservoir beds might be successfully applied there to stimulate output, as has been done elsewhere in treating Ordovician rocks.

The total amount of oil produced from the Naval Reserve field, as compiled from records on file at the Osage Indian Agency, is shown in the following table:

Oil produced from the Naval Reserve fleld

\begin{tabular}{|c|c|c|}
\hline Tract & Date of first production & $\begin{array}{l}\text { Production } \\
\text { to end of } 1938 \\
\text { (barrels) }\end{array}$ \\
\hline 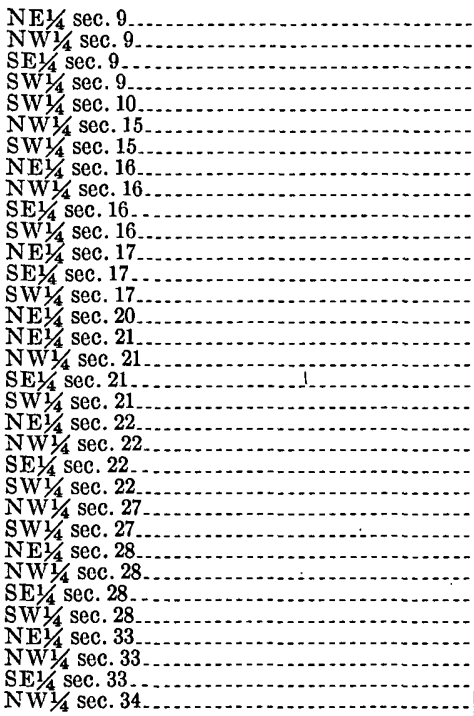 & 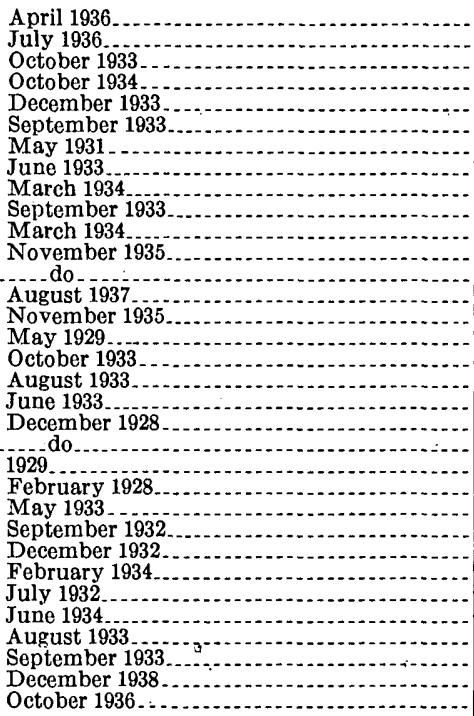 & $\begin{array}{r}290,667 \\
57,420 \\
934,045 \\
342,274 \\
184,891 \\
275,277 \\
281,673 \\
676,651 \\
480,245 \\
994,204 \\
816,665 \\
73,805 \\
360,263 \\
41,621 \\
274,502 \\
1,240,490 \\
1,516,978 \\
798,960 \\
1,305,602 \\
123,436 \\
212,105 \\
219,807 \\
206,082 \\
35,991 \\
245,223 \\
501,225 \\
203,887 \\
372,779 \\
185,433 \\
272,747 \\
85,911 \\
1,764 \\
64,820\end{array}$ \\
\hline & & $13,577,443$ \\
\hline
\end{tabular}

1 Abandoned in September 1938.

If it is assumed that each well in the Naval Reserve field drains 10 acres, the average amount of oil produced to the acre to December 31,1938 , was 5,170 barrels. All except seven of the wells produced their oil from the Burbank sand, and of these seven, six produced oil from Ordovician rocks and one produced from the Mississippi lime.

\section{KASISHKKE FIELD}

The Kasishke field in secs. 24 and 13 is on a small dome whose crest is in the NE1/4 sec. 24. The dome's structural closure on the 
top of the Oswego lime is less than 40 feet. Oil is produced on the dome from Ordovician beds-mainly the Siliceous lime-the uppermost beds of the Mississippi lime, and the Bigheart sand; the depths to the three producing zones are about $2,800,2,500$ and 700 feet, respectively.

Four wells in the $\mathrm{NE}^{1} / 4$ sec. 24 , near the crest of the dome, have produced oil from Ordovician rocks. In these wells some oil was found in the Simpson formation, but most of it occurs in the uppermost few feet of the Siliceous lime. The initial daily yields ranged from 70 to 1,000 barrels to a well. The rate of production of two wells producing from these beds was greatly increased as a result of treatment with acid.

Only one well-No. 3 in the NW1/4 sec. 24-has produced oil from the uppermost chert beds of the Mississippi lime; the initial daily yield of this well was 25 barrels in June 1934 .

A sequence of alternating beds of sand, shale, red shale, and a few thin beds of limestone, with a total thickness of about 70 feet, has produced oil in 19 wells at a depth of about 700 feet. This sequence of beds is believed to represent the Bigheart sandstone, which lies at the base of the Nelagoney formation. The average initial daily yield of the wells was about 35 barrels each. The maximum initial daily yield-170 barrels-was obtained by well 4 in the NE1/4 sec. 24 . Well 5 in the SE1/4 sec. 24 produced gas at an initial daily rate of $1,500,000$ cubic feet from the sand. The oil-bearing sand is being repressured with gas.

It is not improbable that the producing area of the Siliceous lime could be extended eastward in the NE1/4 sec. 24 by the drilling of additional wells; the producing area of the Bigheart sand might be extended northeastward; and during the further development of the field, any shows of oil in the Mississippi lime should be tested, for this field is in a broad northeastward-trending belt that contains many oil pools in the Mississippi lime.

To December 31, 1938, the total yield from all three producing zones in the Kasishke field was about 2,650 barrels to the acre. The total amount of oil produced, as compiled from records on file at the Osage Indian Agency, is shown in the following table:

Oil produced from the Kasishke field

\begin{tabular}{|c|c|c|c|}
\hline Tract & Date of first production & $\begin{array}{l}\text { Production } \\
\text { to end of } 1938 \\
\text { (barrels) }\end{array}$ & Remarks \\
\hline \multirow[t]{2}{*}{$\begin{array}{l}\text { SE1/4 sec. } 13 \\
\text { NE1 } 1 / 4 \text { sec. } 24 \\
\text { NW1 } 1 / 4 \text { sec. } 24 \\
\text { SE1/4 sec. } 24\end{array}$} & \multirow[t]{2}{*}{$\begin{array}{l}\text { December } 1932 \\
\text { May } 1932 \\
\text { June } 1934 \\
\text { September } 1932\end{array}$} & $\begin{array}{r}21,966 \\
267,190 \\
19,683 \\
22,784\end{array}$ & \multirow[t]{2}{*}{ Abandoned in March 1938.} \\
\hline & & 331,623 & \\
\hline
\end{tabular}




\section{RAINBOW ANTICLINE}

An oval-shaped anticline, whose top is broad and flat, occupies parts of secs. 25 and 36 and extends into sec. 30, T. 24 N., R. 8 E. Its structural closure is about 40 feet on the top of the Oswego lime. Only a few wells with small daily yields of oil have been found on the anticline. Well 1 , in the southeast corner of the $\mathrm{NE} 1 / 4$ sec. 25 , produces oil from the uppermost beds in the Siliceous lime at a depth of 2,832 feet. The initial daily yield of the well, in March 1934, was only 10 barrels; and by the end of 1938 its total yield was only 5,446 barrels Four wells, one of which has been abandoned, near the quarter corner common to secs. 25 and 36, produced oil from the uppermost 40 feet of the Mississippi lime at a depth of about 2,530 feet; the initial daily yields of the wells ranged from 3 to 60 barrels each. The Burbank sand, which is a prolific oil producer nearby, in the Naval Reserve field, appears to be absent on the Rainbow anticline.

The total amount of oil produced from the anticline to the end of 1938 is shown in the following table:

Oil produced on the Rainbow anticline

\begin{tabular}{|c|c|c|c|}
\hline Tract & Date of first production & $\begin{array}{l}\text { Produced to } \\
\text { Dec. 31, } 1938 \\
\text { (barrels) }\end{array}$ & Remarks \\
\hline $\begin{array}{l}\text { NE1/4 sec. } 25 \\
\text { SE1/4 sec. } 25 \\
\text { SW11/4 sec. } 25 \\
\text { NE1/4 sec. } 36 \\
\text { NW1/4 sec. } 36 .\end{array}$ & $\begin{array}{l}\text { March } 1934 \\
\text { September } 1933 \\
\text { Septo do }\end{array}$ & $\begin{array}{r}5,446 \\
50,442 \\
590 \\
27,545 \\
16,425\end{array}$ & Abandoned in October 1934. \\
\hline & & 100,448 & \\
\hline
\end{tabular}

\section{NORTHEAST QUARTER OF THE TOWNSHIP}

The positions of the structure contour lines on plate 9 in much of the northeast quarter of the township are speculative, for only a very few wells have been drilled. Nevertheless the anticlinal nose shown in secs. 1 and 12 may deserve investigation. Well 1 in the $\mathrm{NW}_{1} / 4 \mathrm{SW} 1 / 4 \mathrm{NW}_{1} / 4$ sec. 12 produced oil initially in 1933 at the rate of 50 barrels a day; the oil was obtained from the uppermost 22 feet of the Siliceous lime at a depth of 2,900 feet. The well produced a total of 8,884 barrels by September 1937 , when it was abandoned. Well 1 in the $S W 1 / 4 \mathrm{NW}^{1 / 4}$ sec. 11 , low on the west flank of the anticlinal nose, is reported to have had a show of 10 barrels of oil in the Simpson formation. 